\title{
MODELLING TEMPERATURE DISTRIBUTION IN ALPINE
}

\section{GLACIERS}

\author{
by \\ Heinz Blatter \\ (Geographisches Institut ETH, Universität Zürich-Irchel, CH-8057 Zürich, Switzerland) \\ and Wilfried Haeberli \\ (Versuchsanstalt für Wasserbau, Hydrologie und Glaziologie, ETH Zürich, ETH Zentrum, \\ $\mathrm{CH}-8092$ Zürich, Switzerland)
}

\begin{abstract}
ABST RACT
Modelling temperature distribution in nontemperate mountain glaciers presents problems not normally encountered when modelling ice sheets or ice shelves. These problems are mainly concerned with numerical instabilities caused by the high, nonuniform gradients of various input parameters (geometry, mass balance, surface temperature, and flow velocity). Steady-state solutions must be used to check and complete data sets, before using models of greater complexity to calculate temperature fields in a more realistic way. Test runs with a computer model, which allows for true two-dimensional solutions and realistic velocity fields, are described for two examples from the Swiss Alps. These steady-state calculations illustrate, in a semi-quantitative way, that advection of cold ice by glacier flow strongly influences the temperature distribution in both an existing large valley glacier with a cold accumulation zone (Grenzgletscher), and a large piedmont glacier of the last ice age, around $18 \mathrm{ka}$ BP (Rheingletscher). Non-steady-state models are being prepared and tested for future calculations.
\end{abstract}

\section{INT RODUCT ION}

Temperature distribution in polar ice bodies has long been studied; but there is only scant information about temperature distribution in mountain glaciers of temperate regions because these glaciers were of ten assumed to be temperate. Recent data compilations (cf. Haeberli 1975, Huang and others 1982, Hooke and others in preparation*) show that this was a misleading assumption (Paterson 1981). The occurrence of glaciers which are temperate throughout may, in fact, be restricted to regions with heavy precipitation of $>2000 \mathrm{~mm} \mathrm{a}-1$ (Haeberl $i$ in press), and the majority of mountain glaciers in the world may be partially cold. During recent years, there has been increased interest in temperature distribution in Alpine glaciers, in connection with the following fields of study: (a) core drilling projects (e.g. Oeschger and others 1977, Schotterer and others 1981), (b) glacier

*To be published:

Hooke R L, Gould J E, Brzozowski J Near surface temperatures near and below the equilibrium 1 ine on polar and subpolar glaciers. hazards, such as ice avalanches and glacier floods (Röthlisberger 1981, Haeberli 1983), (c) the investigation of geomorphological processes, such as the formation of push moraines (Schindler and others 1978, Haeberli 1979), and (d) palaeoclimatic and geothermal studies (Haeberli and others 1984).

Modelling temperature distribution in mountain glaciers faces problems not normally encountered when modelling polar ice sheets or ice shelves (cf. Paterson 1981). These problems mainly concern the high, nonuniform gradients of geometric parameters (inclination, thickness), flow velocities, net mass balance and surface temperatures. Significant changes in these parameters with time also cause problems. Only non-steadystate models may eventually give realistic results.

Problems of numerical stability still make it necessary to use steady-state solutions to test and complete available input data before using models of higher complexity. This paper briefly discusses input data $(W H)$ and first tests (H B) for two examples from the Swiss Alps. The paper is considered to be a preliminary report about continuing efforts to reach a better understanding of temperatures in glaciers (both existing ones or ones which have long since vanished) of the Alps and other mountain regions.

\section{CASES STUDIED AND DATA INPUT}

Two examples were selected for first model tests: Grenzgletscher, since it is one of the best documented non-temperate glaciers existing in the Alps today, and Rheingletscher, because it is representative of the large piedmont glaciers of the last ice age in Switzerland.

Grenzgletscher is the main stream of Gornergletscher, one of the largest ice bodies of the Alps. cold firn from the higher parts of the accumulation area reappears as strikingly white ice ( $r i c h$ in air bubbles) in the glacier tongue, where the temperature of the ice is still below $0^{\circ} \mathrm{C}$ (Haeberli 1975). Figure 1 gives input data for the whole glacier. Information comes from unpublished reports by Süsstrunk (seismic reflection in the ablation area, cf. Röthlisberger (1972)), Elliston* (surface velocity and net mass

\section{*Unpublished report:}

Elliston G R [1966] Glaciological studies on the Gornergletscher. III: changes in surface speed with time. 
balance in the ablation area) and Schnyder (unpublished) (net balance at high altitudes). Ice thickness in the accumulation area is estimated using a constant width-to-depth ratio ( 5 , cf. Haeberli unpublished); glacier flow at the surface of the firn region where no measurements exist, is estimated by using Glen's flow law for temperate ice (cf. Paterson 1981) and smoothed to eliminate irregularities of short wave1ength. Surface temperatures are estimated and interpolated from bore-hole studies on other Alpine glaciers, on the Colle Gnifetti (km 14, $4450 \mathrm{~m}$ a.s.1., cf. Figs.1 and 2) and on the tongue of the Grenzgletscher ( $\mathrm{km} 5$ and 2, 2600 and $2500 \mathrm{~m} \mathrm{a.s.1.,} \mathrm{cf.}$
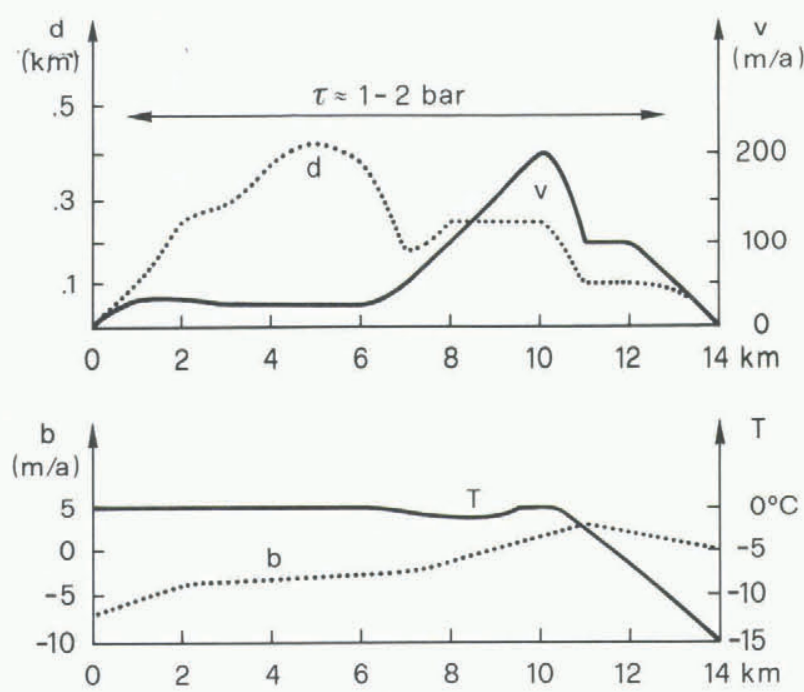

Fig.1. Grenzgletscher: input data for model calculations; $d$ is glacier thickness, $v$ is surface velocity, $b$ is net mass balance, $T$ is $10 \mathrm{~m}$ temperature. The front of the glacier is at $\mathrm{km} \mathrm{0.} \mathrm{High} \mathrm{value} \mathrm{of} \mathrm{basal}$ shear stress $\tau$ indicates high glacier activity in a region with abundant precipitation.

Figs.1, 2, and 5). The most recent temperature measurements in bore holes with in Grenzgletscher are shown in Figure 2.

Rheingletscher was one of the large piedmont glaciers of the Alps in existence during the last ice age. The geometry of this ice body was reconstructed on the basis of geological evidence by Jäckli (1970) and, more recently, by Keller and Krayss (1980). Input parameters are given in Figure 3 . Flow velocities again are calculated with the use of Glen's flow law for temperate ice to obtain upper limits. Balance values are estimated from ice discharge and continuity considerations, and are adjusted to give the balance gradient a more or less constant value (for simplicity). Surface temperatures are based on geocryological reconstructions of periglacial palaeotemperatures, on air-temperature gradients of $0.65^{\circ} \mathrm{C} 100 \mathrm{~m}^{-1}$ (very questionable assumption) and on empirical relationships between air and ice (firn) temperatures (Haeberli 1982). However, all numbers are uncertain, and in some cases (balance gradient, velocity), their accuracy is 1 imited to orders of magnitude only. But it is worth noting that all values indicate clearly that the piedmont glaciers of the last ice age existed under cold and dry climatic conditions (low precipitation + low temperature at the equilibrium line + low mass-balance gradient + low mass flux $\rightarrow$ low shear stress and low velocity, cf. Haeberli (in press)).
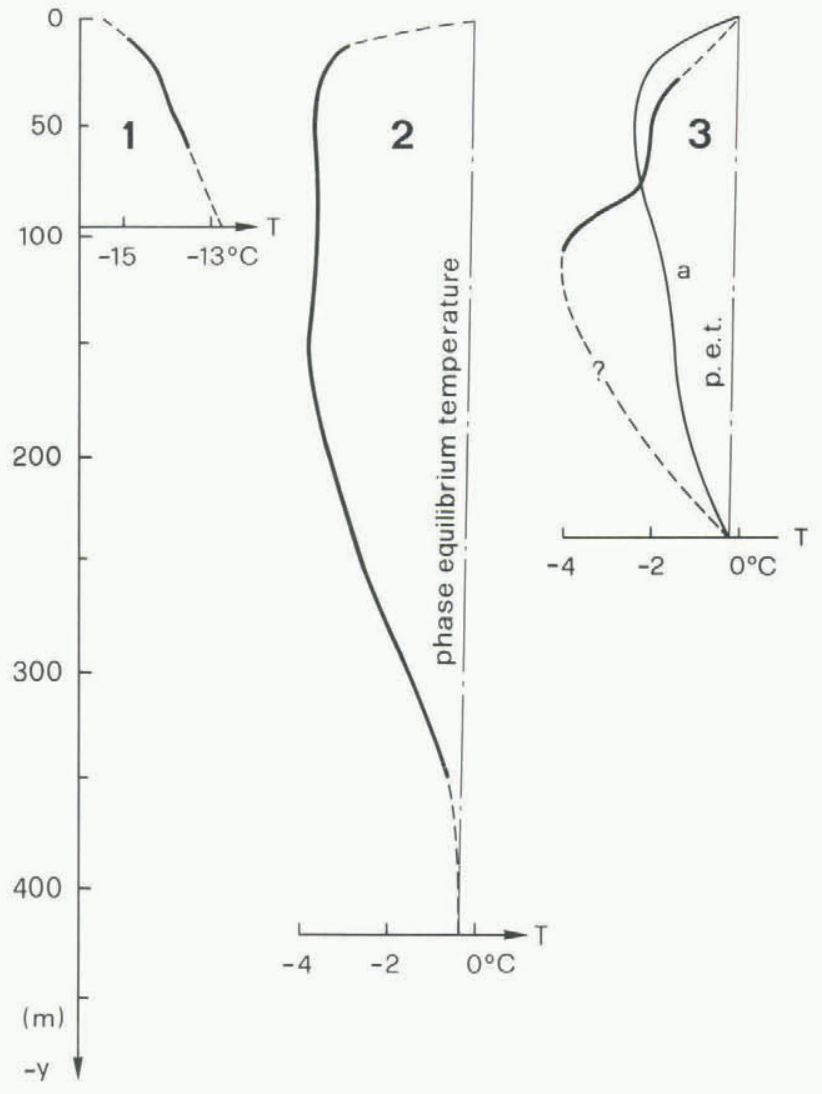

Fig.2. Grenzgletscher: bore-hole temperatures. Level of temperature scale indicates depth $(-y)$ of glacier bed below surface. Bore hole 1: Colle Gnifetti ( $\mathrm{km} \mathrm{14}, \mathrm{y}=0$ at $4450 \mathrm{~m}$ a.s.1., measured in 1978). Bore hole 2: glacier tongue $(\mathrm{km} \mathrm{5}, \mathrm{y}=0$ at $2600 \mathrm{~m}$ a.s.1., measured in 1979). Bore hole 3: glacier tongue $(\mathrm{km} \mathrm{2}, y=0$ at $2500 \mathrm{~m}$ a.s.1., measured in 1980). Indicated temperatures were taken after thermal stabilisation of either the air-filled (bore hole 1) or the water-filled, refrozen bore hole (bore holes 2 and 3 ). Curve a for bore hole 3 is calculated (cf. Fig.5).

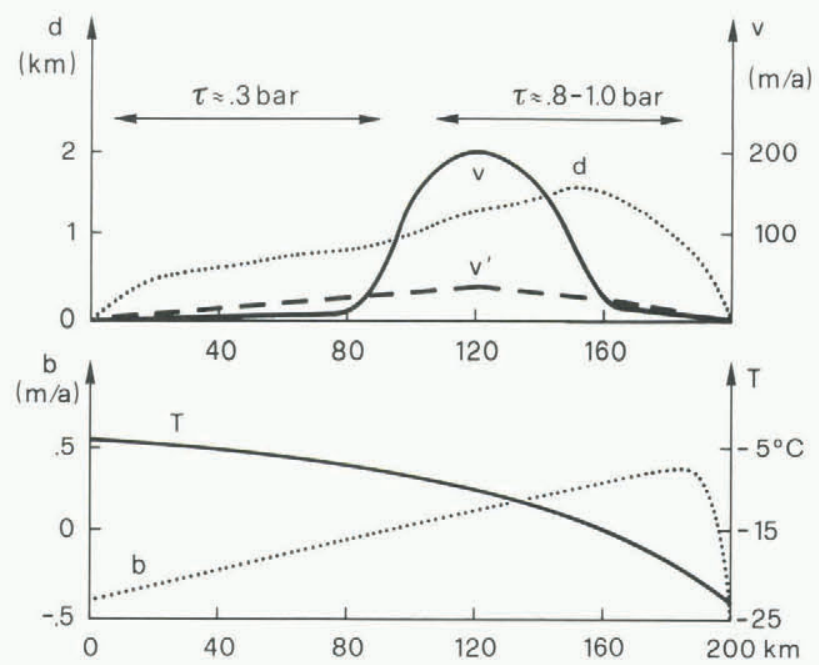

Fig.3. Rheingletscher, 18 ka BP: input data for model calculations. Explanation cf. Figure 1, $v^{\prime}$ is smoothed velocity profile used for test run (cf. Fig.6). Low value of basal shear stress indicates low glacier activity under continental climatic conditions. 


\section{MODEL CALCULATION: TWO-DIMENSIONAL STEADY-STATE} SOLUTION

The differential equation for the two-dimensional distribution of the temperature $T(x, y)$ in a moving medium with constant thermal diffusivity $k$ and a constant geometry with constant boundary conditions is

$$
k \cdot \Delta T(x, y)-\vec{v}(x, y) \cdot \Delta T(x, y)=0 .
$$

$\vec{v}(x, y)$ is the velocity vector as a function of the location $P(x, y)$ :

$$
\vec{v}(x, y)=\left(\begin{array}{c}
v_{x}(x, y) \\
v_{y}(x, y)
\end{array}\right) .
$$

The geometry used for the calculation is illustrated in Figure 4 . The surface of the glacier is taken as

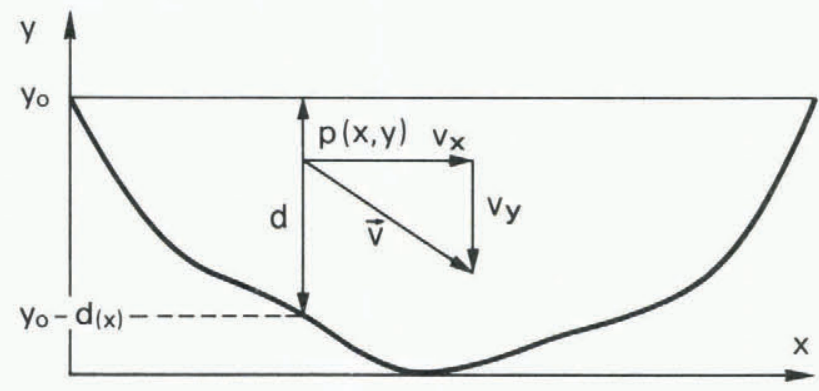

Fig.4. Coordinate system and geometry of the glacier as used for calculations. $\vec{v}$ is the velocity vector at the point $P(x, y)$ and $d$ is the glacier thickness at $x$.

horizontal for $y=y_{0}$ and the glacier bed then follows a 1 ine

$$
y(x)=y_{0}-d(x),
$$

with $d(x)$ as the thickness at the position $x$.

The following assumptions for the velocity field have been made for the calculations: (a). The horizontal velocity component $v_{S}(x)=v_{x}\left(x, y_{0}\right)$ for the glacier surface and the horizontal velocity component $v_{b}(x)=v_{x}\left(x, y_{0}-d(x)\right)$ at the glacier bed (sliding velocity) are either estimated or calculated as explained in the previous section (Fig.1). (b). The horizontal velocity component $v_{x}(x, y)$ as a function of the depth below the surface is calculated using a 4 th power law corresponding to Glen's law for a uniform channel with constant flow-law parameter $A$ and a flow law exponent $n=3$ :

$v_{x}(x, y)=\left(v_{s}(x)-v_{b}(x)\right)\left(1-\left(\frac{y-y_{0}}{d(x)}\right)^{4}\right)+v_{b}(x)$

where $y_{0}-d(x)<y<y_{0}$. (c). The vertical component $v_{y}\left(x, y_{0}\right)$ of the velocity vector at the glacier surface is taken as the negative net mass balance -b as illustrated in E, igures 1 and 3.

(d). The vertical velocity component $v_{y}(x, y)$ as a function of the depth below the surface is taken to be 1 inear:

$$
v_{y}(x, y)=v_{y}\left(x, y_{0}\right)\left(\frac{y-y_{0}+d(x)}{d(x)}\right),
$$

again for $y_{0}-d(x)<y<y_{0}$.

For the chosen geometry, the bed of the glacier is not parallel to the $x$-axis and therefore, the vector components described above do not correspond exactly to the "horizontal" and "vertical" components in reality. This effect is more severe closer to the bed. On the other hand, the velocity decreases closer to the bed and the slope angles are small except for the glacier terminus, and therefore, the error made remains small.

The ELLPACK program (Rice 1980) (available at the ETH-Zürich's program library) was employed for solving two-dimensional elliptic differential equations for steady-state conditions. This program allows the input of a given geometry by defining the margin with curved parts and a boundary condition for each curved part and a given velocity field. As boundary conditions, $a^{\circ}$ temperature function, a temperature gradient or a mixed condition can be used.

With respect to the of ten-used "moving column" model (Radok and others 1970, cf. Hooke 1977, Sugden 1977), the model presented here allows for true twodimensional solutions and can take into account realistic velocity distributions. The result of the computations is replotted for the actual geometry of the glacier.

Figures 5 and 6 show examples of test runs. In the case of Grenzgletscher (Fig.5), the temperature information from bore hole 2 (Fig.2) was used as a

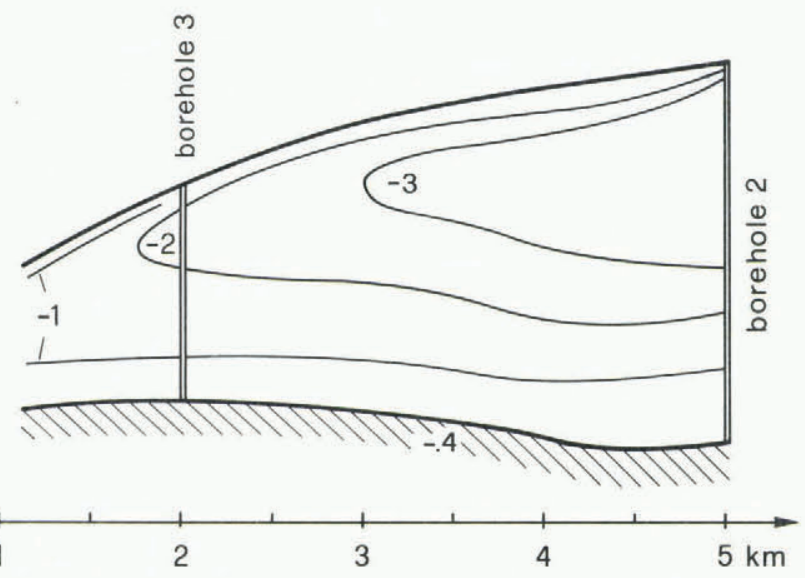

Fig.5. Grenzgletscher: calculated temperature distribution in the region of bore holes 2 and 3 ( $\mathrm{cf}$. Figure 2 for bore-hole information and vertical scale and Figure 1 for surface input data). Boundary condition is $\delta T / \delta x=0$ at $\mathrm{km} 1$ and phase equilibrium temperature at the glacier bed (cf. Harrison 1975). The calculated temperature profile at bore hole 3 is illustrated in Figure 2 .

boundary condition at $\mathrm{km} 5$ to simulate the temperature distribution in a down-glacier section measuring $4 \mathrm{~km}$ in length; bore hole 3 is also sited with in this distance, at $\mathrm{km} 2$. In addition to the surface data (cf. Fig.1), a constant temperature at the glacier bed (approximately corresponding to the phase equilibrium temperature) and a zero gradient $\delta T / \delta x=0$ at the vertical end at $\mathrm{km} 1$ were chosen as boundary conditions. As a result, the calculated temperature distribution corresponds in a qualitative way to the temperature profile observed in bore hole 3 (Fig.6). However, the model gives somewhat higher temperatures and does not simulate the observed irregularities of the temperature profile in detail. Deviations of the observed profile with respect to the calculated profile are thought to be due to historical changes in glacier geometry, ice flow and surface boundary conditions. More complete temperature measurements and non-steady-state calculations are therefore necessary to reach better agreement between observation and calculation. Despite these uncertainties, the calculation illustrates the fact that cold glacier ice can be easily transported over long distances by the movement of the ice in Alpine glaciers, even within zones of temperate surface temperatures. No model cal- 


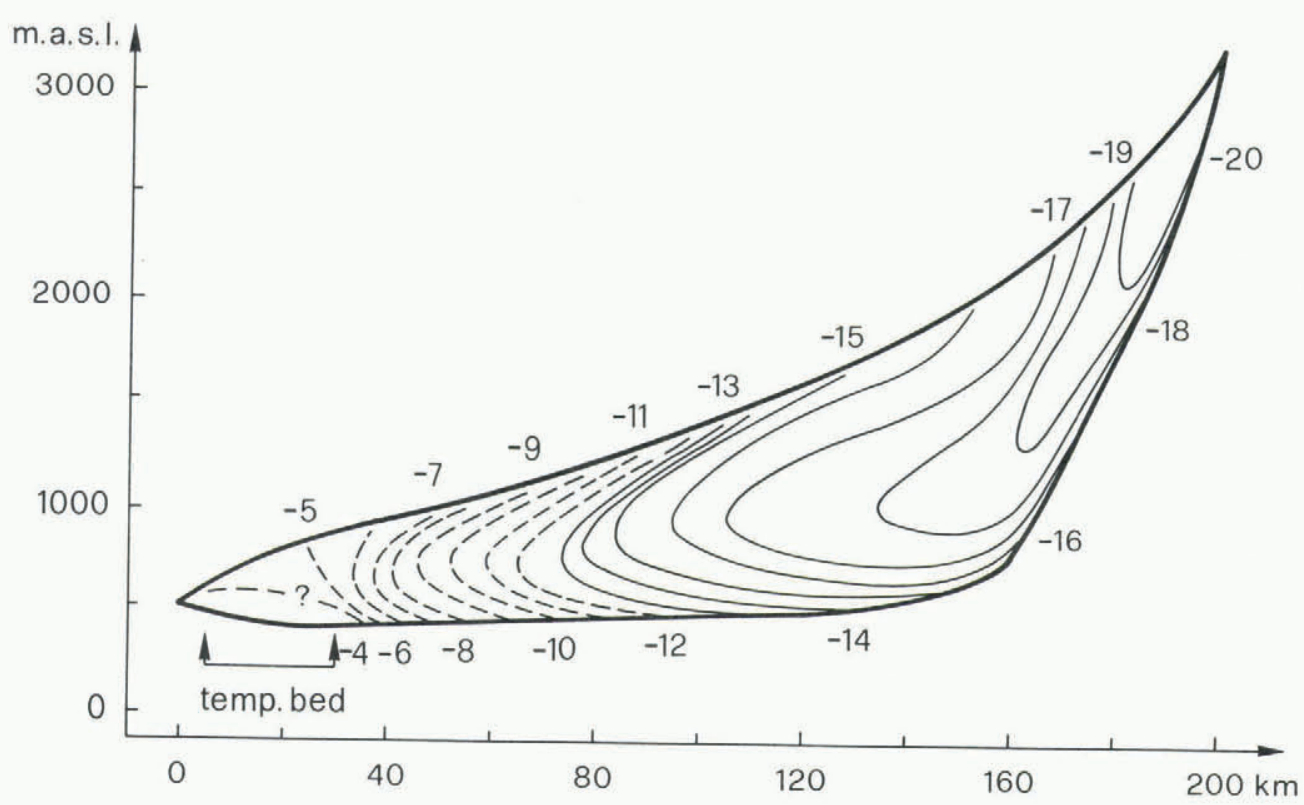

Fig.6. Rheingletscher, 18 ka BP: calculated temperature distribution. Broken lines indicate regions of numerical instability in the calculation.

culation has been done so far for the entire glacier. The results of the test run between bore holes 2 and 3 and the high velocity of the ice in the accumulation area as indicated in Figure 1, however, make it easy to assume that advection of cold ice from the highaltitude part of the accumulation area is indeed the cause of the temperature distribution in bore hole 2 (Fig.2) and in the glacier tongue.

The example of Rheingletscher (Fig.7), the iceage glacier of $18 \mathrm{ka} \mathrm{BP}$, again shows the strong effect of ice advection on the englacial temperature distribution. In addition to surface data (cf. Fig.3), $\delta T / \delta y$ at the glacier bed was chosen as $0.015^{\circ} \mathrm{C} \mathrm{m}^{-1}$ about half the value actually observed in the Swiss plateau). The choice of this important boundary condition illustrates perfectly the uncertainty of steadystate calculations. Both the temperature of the glacier bed and the temperature gradient vary with changes in all other parameters. Also, the calculated temperature gradient at the glacier bed, aga in makes the choice of boundary conditions difficult. In fact, it is possible to construct almost every desired englacial temperature distribution by varying this input parameter. The chosen value represents a rough compromise; near the glacier front, where relatively warm glacier ice may have overridden relatively cold (perennially frozen) ground, heat flow may have been extremely weak, zero or even negative (into the earth), and $0.015^{\circ} \mathrm{C} \mathrm{m}^{-1}$ may be too large a temperature gradient. However, 30 to $50 \mathrm{~km}$ behind the front, where very cold ice must have overridden relatively warm (thawed) ground, much higher temperature gradients probably occurred. Thus, the boundary condition at the glacier bed should be varied as a function of $x$, but this will only be possible on the basis of improved knowledge about temperature variations and glacier fluctuations as functions of time. The example of Rheingletscher also illustrates the problem of numerical instability. The velocity profile calculated from the reconstructed glacier geometry had to be smoothed by a factor of about 5 ( $v^{\prime}$ in Fig.3), to allow for more or less stable solutions. Even then, however, the lower part of the glacier (the "ablation area") remained highly unstable. Thus, this model is probably more useful for testing the sensitivity of the temperature field to various parameters (e.g. variations in boundary conditions, variation of the velocity field of the ice movement and variations of the thermal properties, like thermal diffusivity as a function of the location or of the temperature itself) rather than for simulating accurately the temperature distribution in existing or former glaciers. Nevertheless, the calculation of the temperatures for Rheingletscher indicates that the glacier bed may have been temperate only in a relatively narrow zone near the glacier front, and that very cold ice was brought down to low altitudes by ice movement. This latter effect may have greatly enhanced the depression of temperatures during $18 \mathrm{ka}$ BP at the Earth's surface in certain regions. For example, in the region of Sargans at $\mathrm{km} \mathrm{120,}$ ground surface temperatures may have been colder than in periglacial regions with the same altitude by about $10^{\circ} \mathrm{C}$, thus greatly enhancing geothermal effects in the Earth's crust (cf. Haeberli and others 1984).

CONCLUSIONS AND OUTLOOK: NON-STEADY-STATE SOLUTIONS

The results of modelling the temperature distribution in Grenz- and Rheingletscher clearly point to the importance of ice advection in non-temperate mountain glaciers. However, they also show that accurate modelling of such glaciers is only possible if the combined history of boundary conditions and glacier fluctuations can be considered in non-steadystate type calculations. Another program, using finite elements, is being prepared. It solves the same differential equation, in this case for timedependent boundary conditions, but still for a nonvariable geometry. Only such non-steady-state calculations may eventually give more realistic results. At the present level of knowledge steady-state solutions may help to improve the incomplete data basis as well as our understanding of the complicated and interdependent processes involved.

\section{ACKNOWLEDGEMENTS}

The authors are grateful to Pamela Alean for helping with the editing of the manuscript, and to Werner Nobs for preparing the diagrams.

\section{REFERENCES}

Haeberli W 1975 Eistemperaturen in den Alpen. Zeitschrift fur Gletscherkunde und Glazialgeologie $11(2): 203-220$

Haeberli w 1979 Holocene push-moraines in Alpine permafrost. Geografiska Annaler 61A(1-2): 43-48 
Haeberli $W$ Unpublished Kritische Bemerkungen zum Problem der Schubspannungsberechnung für alpine Gletscher. [Abstract. 12. Internationale Polartagung in Innsbruck, 21-24 April 1981]

Haeberli W 1982 Klimarekonstruktionen mit Gletscher-Permafrost-Beziehungen. Basler Beiträge zur Physiogeographie 4: 9-17

Haeberli $W 1983$ Frequency and characteristics of glacier floods in the Swiss Alps. Annals of Glaciology 4: 85-90

Haeberli $W$ In press Permafrost-glacier relationships in the Swiss Alps - today and in the past. In Fourth Intermational Conference on Permafrost, Fairbanks, Alaska, 1983. Proceedings

Haeberli W, Rellstab W, Harrison W D 1984 Geothermal effects of $18 \mathrm{ka} B P$ ice conditions in the Swiss plateau. Annals of Glaciology 5: 56-60

Harrison W D 1975 Temperature measurements in a temperate glacier. Joumal of Glaciology 14(70): 23-30

Hooke R LeB 1977 Basal temperatures in polar ice sheets: a qualitative review. Quatemary Research 7(1): $1-13$

Huang Maohuan, Wong Zhongxiang, Ren Jiawen 1982 On the temperature regime of continental-type glaciers in China. Joumal of Glaciology 28(98): 117-128

Jäckli H 1970 Die Schweiz zur letzten Eiszeit. Atlas der Schweiz Blatt 6. Wabern-Bern, Eidgenössiche Landestopographie

Keller 0, Krayss E 1980 Die letzte Vorlandvereisung in der Nordostschweiz und im Bodensee-Raum (Stadialer Komplex Würm - Stein am Rhein). Eclogae Geologicae Helvetiae 73(3): 823-838

Oeschger H, Schotterer U, Stauffer B, Haeberli W, Röthl isberger $\mathrm{H} 1977$ First results from Alpine core drilling projects. Zeitschrift fur Gletschen kunde und Glazialgeologie 13(1/2): 193-208

Paterson W S B 1981 The physics of glaciers. Second edition. Oxford etc, Pergamon Press

Radok U, Jenssen D, Budd W F 1970 Steady-state temperature profiles in ice sheets. Intermational Association of Scientific Hydrology Publication 86 ( ISAGE): 151-165

Rice J R 1980 Ellpack 78 user's guide - preliminary version. West Lafayette, IN, Purdue University. Computer Science Departinent (Technical Report 306) (1979, revised 1980)

Röthlisbeger H 1972 Water pressure in intra- and subglacial channels. Joumal of Glaciology 11(62): 177-203

Röthlisberger H 1981 Eislawinen und Ausbrüche von Gletscherseen. Jahrbuch der Schweizerischen Natur forschenden Gesellschaft, Wissenschafticher Teil 1978: 170-212

Schindler C, Röthlisberger H, Gyger M 1978 Glaziale Stauchungen in den Niederterassen-Schottern des Aadorfer Feldes und ihre Deutung. Eclogae GeoZogicae Helvetiae 71(1): 159-174

Schnyder B Unpublished Glaziologische Untersuchungen und Messungen im Raume Zermatt. Arbeitsbericht Grande Dixence S.A. 1972

Schotterer U, Haeberli $W$, Good $W$, Oeschger $H$, Röthlisberger $H \quad 1981$ Datierung von kaltem Firn und $E$ is in einem Bohrkern vom Colle Gnifetti, Monte Rosa. Jahrbuch der Schweizemischen Naturforschenden Gesellschaft, Wissenschaftlicher Teil 1978: 48-57

Sugden DE 1977 Reconstruction of the morphology, dynamics, and thermal characteristics of the Laurentide ice sheet at its maximum. Arctic and Alpine Research 9(1): 21-47 